\title{
STRUCTURAL DESIGN AND ANALYSIS OF THE UPPER PRESSURE SHELL SECTION OF A COMPOSITE CREW MODULE
}

\author{
David W. Sleight and David Paddock \\ NASA LaRC, Hampton, VA, 23681, USA \\ david.w.sleight@nasa.gov, david.a.paddock@nasa.gov \\ Jim Jeans \\ Genesis Engineering Solutions, Inc., Lanham, MD 20706, USA \\ jwjeans@vt.edu \\ John Hudeck \\ NASA GSFC, Greenbelt, MD, 20771, USA \\ john.d.hudeck@nasa.gov
}

\begin{abstract}
This paper presents the results of the structural design and analysis of the upper pressure shell section of a carbon composite demonstration structure for the Composite Crew Module (CCM) Project. The project is managed by the NASA Engineering and Safety Center with participants from eight NASA Centers, the Air Force Research Laboratory, and multiple aerospace contractors including ATK/Swales, Northrop Grumman, Lockheed Martin, Collier Research Corporation, Genesis Engineering, and Janicki Industries. The paper discusses details of the upper pressure shell section design of the CCM and presents the structural analysis results using the HyperSizer ${ }^{\circledR}$ structural sizing software and the MSC Nastran ${ }^{\circledR}$ finite element analysis software. The HyperSizer ${ }^{\circledR}$ results showed that the controlling load case driving most of the sizing in the upper pressure shell section was the internal pressure load case. The regions around the cutouts were controlled by internal pressure and the main parachute load cases. The global finite element analysis results showed that the majority of the elements of the CCM had a positive margin of safety with the exception of a few hot spots around the cutouts. These hot spots are currently being investigated with a more detailed analysis. Local finite element models of the Low Impact Docking System (LIDS) interface ring and the forward bay gussets with greater mesh fidelity were created for local sizing and analysis. The sizing of the LIDS interface ring was driven by the drogue parachute loads, Trans-Lunar Insertion (TLI) loads, and internal pressure. The drogue parachute loads controlled the sizing of the gusset cap on the drogue gusset and TLI loads controlled the sizing of the other five gusset caps. The main parachute loads controlled the sizing of the lower ends of the gusset caps on the main parachute fittings. The results showed that the gusset web/pressure shell and gusset web/gusset cap interfaces bonded using Pi-preform joints had local hot spots in the Pi-preform termination regions. These regions require a detailed three-dimensional analysis, which is currently being performed, to accurately address the load distribution near the Pi-preform termination in the upper and lower gusset caps.
\end{abstract}

\section{Introduction}

In January 2007, the NASA Engineering and Safety Center (NESC) was chartered to design and build, using mostly composite materials and design techniques, a CEV-like crew module. The main objective of the Composite Crew Module (CCM) project is for NASA personnel to gain hands-on experience in designing, building, and testing a full scale, composite, habitable spacecraft in anticipation that future exploration systems are likely to be made of composite materials. Key design and analysis assumptions are validated by resolving design details through fabrication and testing of hardware. The 
NESC managed project includes participants from eight NASA Centers, the Air Force Research Laboratory (AFRL), and multiple aerospace contractors including ATK/Swales, Northrop Grumman, Lockheed Martin, Collier Research Corporation, Genesis Engineering, and Janicki Industries. The design and fabrication of the CCM is to be accomplished in 18 months. The CCM project had a Preliminary Design Review (PDR) in June 2007 and a Critical Design Review (CDR) in December 2007. Prior to the CCM project, a multi-center NASA team was formed to perform a preliminary composite crew module design and the team identified additional design drivers as they apply to composites, such as manufacturability, crashworthiness, damage tolerance, inspectability, reparability, and the effects of micro-meteoroid orbital debris (MMOD) impacts (Kirsch et al., 2007; Bednarcyk et al., 2007).

The CCM, shown in Fig. 1, is a pressure module that is divided into upper and lower shell sections that mate together with a bonded "belly band" slice joint. The CCM design is based on the Lockheed-Martin Crew Exploration Vehicle (CEV) design with the external interfaces (see Fig. 2) frozen for the CCM configuration. The CCM has external interfaces with the Alternate Launch Abort System (ALAS) and the Service Module (SM). Other interfaces include the Low Impact Docking System (LIDS) ring and the main and drogue parachute attachment locations as shown in Fig. 1.

The CCM team formed small groups to design and analyze the major sections of the CCM. This paper presents the structural design and analysis results of the upper pressure shell section as presented at the CDR. The first section of the paper describes the CCM design including design requirements, design loads, and materials. Details of the upper pressure shell section design are also described. The next section of the paper describes the structural analysis of the CCM using the HyperSizer ${ }^{\circledR}$ structural sizing software (HyperSizer ${ }^{\circledR}$, 2007) and MSC Nastran ${ }^{\circledR}$ finite element analysis (FEA) software system (MSC Nastran $^{\circledR}$, 2005) for the global model and local models including the LIDS interface ring and the forward bay gussets. Structural analysis results including failure modes, controlling load cases, and margins of safety are presented and discussed for the CCM design.

\section{CCM Design}

\section{Design Requirements}

The CCM team followed the requirements in the NASA Constellation Program's Structural Design and Verification Requirements (SDVR) document in order to maintain consistency in the design, development, and verification with all other Constellation flight hardware. Specific requirements state that the strength and stiffness of the structure must support ultimate load without failure and the design must have zero or positive margins of safety for all ultimate load conditions, including the effects of aging on the hardware. In addition, buckling shall not cause structural members that are subject to instability to collapse when ultimate loads are applied. 


\section{Design Loads}

The CCM design loads were based on the major mission events in the life of the CEV including launch, abort scenarios, on-orbit operations, entry, and landing as shown in Tables 1-4. The design launch load cases included acceleration loads, dynamic pressures, and cabin pressure loads for liftoff and ascent. The design abort load cases included acceleration loads, dynamic pressure loads, and cabin pressure loads for pad abort and abort during the boost mission phase. The design on-orbit load cases included accelerations and cabin pressures for on-orbit operations such as Trans-Lunar Insertion (TLI) burn, Lunar Orbit Insertion (LOI) burn, and Trans-Earth Insertion (TEI) burn as well as internal pressure at the International Space Station (ISS). The design entry and landing load cases included acceleration loads, dynamic pressures, and cabin pressures for atmospheric entry, recovery, and landing. The CCM project finalized the design loads shortly after the PDR. The CCM team recognized that the CEV loading environment will be constantly changing as the project moves forward, but plans to reconcile differences between CEV and CCM design loads as a deliverable of the project. All loads were applied as ultimate loads with a Factor of Safety (FOS) of 1.4 times the limit loads with the exception of the internal pressure load case which had a FOS of 2.0.

\section{Materials}

The composite materials used in the CCM consisted of an IM7/977-2 tape and 4-harness satin fabric. Open hole tensile and compressive coupon test data was used to determine the A-basis damage tolerant tension and compression strain allowables $\left(\varepsilon_{1}{ }^{\text {tu }}\right.$ and $\left.\varepsilon_{1}{ }^{\mathrm{cu}}\right)$ for the tape and fabric. Using the damage tolerant tension and compression strain allowables and the prepreg elastic properties in both material directions $\left(E_{1 t}, E_{1 c}, E_{2 t}, E_{2 c}\right)$, the tensile $\left(\mathrm{F}_{1}{ }^{\mathrm{tu}}\right.$ and $\left.\mathrm{F}_{2}{ }^{\mathrm{tu}}\right)$ and compressive $\left(\mathrm{F}_{1}{ }^{\mathrm{cu}}\right.$ and $\left.\mathrm{F}_{2}{ }^{\mathrm{cu}}\right)$ failure strengths were calculated for the tape and fabric by:

Tape and Fabric:

$$
\begin{aligned}
& \mathrm{F}_{1}{ }^{\mathrm{tu}}=\varepsilon_{1}{ }^{\mathrm{tu}} \mathrm{E}_{1} ; \mathrm{F}_{1}{ }^{\mathrm{cu}}=\varepsilon_{1}{ }^{\mathrm{cu}} \mathrm{E}_{1} \\
& \text { where } \mathrm{E}_{1}=\operatorname{average}\left(\mathrm{E}_{1 \mathrm{t}}, \mathrm{E}_{1 \mathrm{c}}\right)
\end{aligned}
$$

Tape:

$$
\begin{gathered}
\mathrm{F}_{2}{ }^{\mathrm{tu}}=\varepsilon_{2}{ }^{\mathrm{tu}} \mathrm{E}_{2} ; \mathrm{F}_{2}{ }^{\mathrm{cu}}=\varepsilon_{2}{ }^{\mathrm{cu}} \mathrm{E}_{2} \\
\text { where } \mathrm{E}_{2}=\operatorname{average}\left(\mathrm{E}_{2 \mathrm{t}}, \mathrm{E}_{2 \mathrm{c}}\right), \varepsilon_{2}{ }^{\mathrm{tu}}=\varepsilon_{2}{ }^{\mathrm{cu}}=\operatorname{average}\left(\varepsilon_{1}{ }^{\mathrm{tu}}, \varepsilon_{1}{ }^{\mathrm{cu}}\right)
\end{gathered}
$$

Fabric:

$$
\begin{gathered}
\mathrm{F}_{2}{ }^{\mathrm{tu}}=\varepsilon_{2}{ }^{\mathrm{tu}} \mathrm{E}_{2} ; \mathrm{F}_{2}{ }^{\mathrm{cu}}=\varepsilon_{2}{ }^{\mathrm{cu}} \mathrm{E}_{2} \\
\text { where } \mathrm{E}_{2}=\operatorname{average}\left(\mathrm{E}_{2 \mathrm{t}}, \mathrm{E}_{2 \mathrm{c}}\right), \varepsilon_{2}{ }^{\mathrm{tu}}=\varepsilon_{1}{ }^{\mathrm{tu}} \text {, and } \varepsilon_{2}{ }^{\mathrm{cu}}=\varepsilon_{1}{ }^{\mathrm{cu}}
\end{gathered}
$$

A V-notch shear test on $0^{\circ} / 90^{\circ}$ laminates with an A-basis factor and environmental knockdown factors was used to determine the in-plane shear allowable $\left(\mathrm{F}_{12}{ }^{\mathrm{su}}\right)$. The 
Hoffman ply-based failure theory (Hoffman, 1967) was used to size the composite regions of the CCM,

$$
\left(\frac{1}{\mathrm{~F}_{1}^{\mathrm{tu}}}-\frac{1}{\mathrm{~F}_{1}^{\mathrm{cu}}}\right) \sigma_{1}+\left(\frac{1}{\mathrm{~F}_{2}^{\mathrm{tu}}}-\frac{1}{\mathrm{~F}_{2}^{\mathrm{cu}}}\right) \sigma_{2}+\frac{\sigma_{1}^{2}}{\mathrm{~F}_{1}^{\mathrm{tu}} \mathrm{F}_{1}^{\mathrm{cu}}}+\frac{\sigma_{2}^{2}}{\mathrm{~F}_{2}^{\mathrm{tu}} \mathrm{F}_{2}^{\mathrm{cu}}}+\frac{\tau_{12}{ }^{2}}{\left(\mathrm{~F}_{12}^{\mathrm{su}}\right)^{2}}-\frac{\sigma_{1} \sigma_{2}}{\mathrm{~F}_{1}^{\mathrm{tu}} \mathrm{F}_{1}^{\mathrm{cu}}}<1
$$

where $\sigma_{1}$ is the applied stress in the " 1 " or fiber direction, $\sigma_{2}$ is the applied stress in the "2" direction, and $\tau_{12}$ is the applied in-plane shear stress.

Interlaminar shear and tension design allowables were also determined from coupon test data and used in the sizing of the CCM. An aluminum non-perforated honeycomb core was used in the sandwich areas of the CCM design with core densities ranging from 3.1 $\mathrm{lb} / \mathrm{ft}^{3}$ to $6.9 \mathrm{lb} / \mathrm{ft}^{3}$. The IM7/MTM45-1 composite was used for the 3D woven Pi-preforms joints (See Fig. 3) to attach the gussets to the pressure shell and the gusset caps to the gussets. Fig. 3 shows the details of a Pi-preform joint in which a web is paste bonded to the laminate skin. Pi-preform shear and pull-off tests were performed during the CCM project to determine allowables for design. Due to International Traffic in Arms Regulations (ITAR) restrictions, the material properties and design allowables for all previously mentioned materials cannot be disclosed.

\section{Upper Pressure Shell Design}

The upper pressure shell is a combined sandwich and solid laminate construction with IM7/977-2 facesheets and solid laminates, and an aluminum non-perforated sandwich core. All laminates are symmetric and balanced. The upper pressure shell's components are the LIDS interface ring, LIDS/tunnel attachment, main and drogue parachute fittings, forward bay gussets and gusset caps, and the window and main hatch cutouts and frames as shown in Fig. 1. The tunnel and main parachute regions of the CCM are solid laminates with thicknesses ranging from $0.08^{\prime}$ to $0.56^{\text {” }}$ thick. The minimum gage for solid laminate regions is eight plies $\left(45^{\circ} / 0^{\circ} / 0^{\circ} / 45^{\circ}\right)_{s}$. The ceiling and conic wall sections of the CCM are of sandwich construction. The facesheets have symmetric layups with a minimum thickness of four plies $\left(45^{\circ} / 0^{\circ} / 0^{\circ} / 45^{\circ}\right)$ consisting mostly of fabric plies with tape plies used for directional strength. A minimum 20:1 ply drop-off ratio is used to transition changes in the laminate thickness. The sandwich regions use a one inch thick aluminum core with seven degree edge tapes for transitions to solid laminate regions. Most sandwich regions have a core density of $4.4 \mathrm{lb} / \mathrm{ft}^{3}$ with a maximum core density of $6.9 \mathrm{lb} / \mathrm{ft}^{3}$. Formed core is used in the shoulder and center curved areas (near the splice joint) of the CCM.

Fig. 4 shows a CAD model of the upper pressure shell section with the LIDS interface ring, forward bay gussets, and the main parachute fittings. The LIDS interface ring is a machined aluminum 7050-T7451 plate to be consistent with the CEV design. The function of the LIDS interface ring is to provide drogue parachute load application points, an upper sealing surface for maintaining internal pressure, and structural support to the tunnel region. The LIDS interface ring is paste-bonded to the tunnel's solid laminate 
inner surface, which has a $5^{\circ}$ taper (on radius) to ensure accuracy of the bondline thickness. Six discreet, pre-cured, solid laminate "doublers" are paste-bonded to the assembly's inside surface to balance the joint and provide reinforcement, as shown in Fig. 5. As shown in Figs. 4 and 6, shear fasteners attach the LIDS interface ring to the gusset web (three each) and caps (six at the drogue chute location, four each at the other locations).

The forward bay gussets serve multiple structural purposes: provide six primary load paths from the pressure shell side wall to the LIDS interface ring; provide stability for the CCM ceiling, tunnel, and forward bay; provide support and strength to the main parachute fittings; serve as reinforced attachments for the crew pallet supports on the inside wall; and serve as an attachment structure for forward bay subsystems. The six gusset webs are constructed of minimum gage facesheets with a one inch-thick honeycomb core. Solid composite inserts reinforce the gusset webs for fastener bearing loads, as shown in Figs. 6 and 7. Each gusset web is bonded to the pressure shell outer wall and to the gusset caps using Pi performs. In addition to the LIDS ring fasteners, the webs are also bolted to the parachute fittings with two fasteners each (see Fig. 6). The lower gusset caps are bolted to the parachute fittings with four fasteners each.

Three main parachute fittings at the base of the gussets, constructed of aluminum 7050T7451, are bolted to the CCM conic wall and ceiling outer mold line (OML) solid laminate regions as shown in Fig. 7. The main function of each of the main parachute fittings is to support the $64,412 \mathrm{lb}$ ultimate load applied at each of the fittings. The main parachute fittings are bolted to the gusset cap with four fasteners and to the gusset web with two fasteners.

The window and hatch cutouts of the CCM accommodate the size and sealing requirements of the main pressure shell cutouts. Each cutout is reinforced with an aluminum, post-bonded, Z-section frame suitable for O-ring sealed covers during pressure testing.

\section{CCM Sizing and Analysis}

\section{Global Finite Element Model Sizing and Analysis}

For the CDR, a global finite element model (FEM) of the CCM was developed and a finite element analysis (FEA) using MSC Nastran ${ }^{\circledR}$ was performed for all of the design loads. The global FEM was used to size the acreage areas of the CCM. The CCM model without the aeroshell and heat shield contained 29,300 elements and 27,100 nodes as is shown in Fig. 8. The model had an average element size of 2 inches. The various color regions represent regions of the same lay-up (PCOMP) in the model.

The HyperSizer ${ }^{\circledR}$ structural sizing software tool was used in the sizing of the CCM. HyperSizer $^{\circledR}$ is a program that couples with finite element analysis to provide system level performance assessments and weight predictions using design optimization of 
materials selections and sizing of structural components. HyperSizer ${ }^{\circledR}$ iterates with MSC Nastran ${ }^{\circledR}$ in the structural sizing process by retrieving the FEA element forces and performs detailed sandwich and laminate failure analyses to size each structural component using HyperSizer's failure analyses based on aerospace structural methods for strength, stiffness, and stability. A component is a region where the lay-up and core density is constant and is identified by grouping elements together with that particular PCOMP property. For solid laminate regions, ply-by-ply composite strength failure analysis checks for in-plane stresses (using the Hoffman failure theory) and out-of-plane interlaminar shear stresses were used to size each region in the model. For sandwich regions, facesheet and core analyses including effects such as flatwise tension at areas of small radius of curvature and core failures for out-of-plane loads were also included in the HyperSizer ${ }^{\circledR}$ failure analyses. Local buckling failure analyses are also included in the HyperSizer $^{\circledR}$ sizing process. The buckling analyses included biaxial buckling of cylindrical and conical panels, shear buckling, and buckling of beam flanges. Lastly, Pipreform pull-off and shear failure checks were performed on all Pi-preform joints based on the design allowables.

Multiple lay-ups were defined in HyperSizer ${ }^{\circledR}$ for the sandwich and solid laminates regions by varying the stacking sequence and number of plies. Each component was sized based on the element forces to determine the lightest component design that produced positive margins for all applicable failure analyses. A component's “design-to" load was determined in HyperSizer ${ }^{\circledR}$ as the highest element force from all load cases analyzed. Each element was required to have a positive margin of safety (MS) within each structural component. After sizing the structural components in the model in which the optimum materials and composite lay-ups were determined, HyperSizer ${ }^{\circledR}$ generated the material properties including the stacking sequence (PCOMP) for the next iteration of the FEA. The iterative process of running the FEA in MSC Nastran ${ }^{\circledR}$ and then performing the sizing in HyperSizer ${ }^{\circledR}$ was repeated until the structure's weight has converged as indicated by stability in the weight and design. After the sizing process was completed, HyperSizer ${ }^{\circledR}$ provided the capability of displaying the margin of safety, failure modes, and critical load cases.

The global CCM FEM was analyzed using linear static analyses for a reduced set of the design loads in Tables 1-4. Due to enveloping of the loads, not all of the design loads in Tables 1-4 were applied to the FEM. The model was constrained by pinning the translational degree of freedom (DOF) at the SM/ALAS fittings for the launch load cases and was free using inertial relief for the abort, TLI, and landing load cases. The controlling load cases for the front and back sides of the upper pressure shell section of the global FEM are shown in Figs. 9 and 10, respectively. The LIDS interface ring, gussets, and main parachute fittings are not shown and will be discussed later in the paper in detailed analysis sections. The HyperSizer ${ }^{\circledR}$ results showed that the controlling load case driving most of the sizing based on the number of elements was the internal pressure load case. The regions around the cutouts were controlled by internal pressure and the main parachute load cases. The sized facesheet thicknesses for the upper pressure shell are shown in Fig. 11. The scale shows the number of structural components in each thickness band which ranges from minimum gage to a 24-ply laminate. The regions in 
gray are thicker laminates. The MS for all load cases is shown in Fig. 12. The results showed that only 2 elements in the upper pressure shell have a negative margin of safety. Both of the elements with negative MS were only slightly negative and located near a cutout. Minimum sized frames were included around the cutouts in the analysis for basic stiffness, forcing the laminate to carry the entire load. These hot spots are currently being investigated with a more detailed analysis. Strain contour plots of the CCM global FEM are shown in Figs.13 and 14 for the internal pressure load case and the high altitude abort load case, respectively. The deformed shape shown in the figures is shown at a scale of 20 times the actual deformation.

\section{Local Finite Element Model Sizing and Analysis}

Local finite element models with greater mesh fidelity compared to the global FE model were created for local sizing and analysis checks. The next two subsections describe the local element models and analyses for the LIDS interface ring and the forward bay gussets.

\section{LIDS Interface Ring}

A detailed FEM of the LIDS interface ring and the tunnel was developed for local sizing and analysis. HyperSizer ${ }^{\circledR}$ was not used for sizing of the LIDS interface ring. Instead, the von Mises failure criterion was used for stress evaluation and hand sizing. The model shown in Fig. 15 was developed by splicing a detailed shell FEM of the LIDS interface ring and tunnel with the global FEM. Its purpose was to capture the appropriate stiffness and load path of the LIDS interface ring. Modeling features included stiff beam elements to represent fasteners and appropriate offsets used at gusset cap and Pi joint interfaces. The mesh was relatively fine with a baseline element size of 0.5 inches. The drogue parachute, TLI, and internal pressure load cases were considered in the MSC Nastran ${ }^{\circledR}$ linear static analysis. In order to capture the appropriate boundary conditions, two FE models were used, one for TLI and the other for drogue chute and internal pressure loading conditions. The TLI model contained point elements representing the stack of the Earth Departure Stage (EDS), Lunar Surface Access Module (LSAM), and the Service Module (SM). A thrust force was applied at the end of the stack. RBE2 elements were used to distribute forces to the LIDS interface ring of the CCM. Fig. 17 shows the drogue parachute loading condition which applies a limit load of 34,243 lbs vertically $\left(0^{\circ}\right)$ and at $40^{\circ}$ cone angles clocked around every $45^{\circ}$ in a circular fashion. All analyses were run to ultimate loads under inertia relief boundary conditions.

Figure 18 shows a deformation plot of the LIDS interface ring due to the $0^{\circ}$ vertical drogue parachute load case. The drogue parachute loading causes significant local bending of the LIDS interface ring and the gusset cap. Figure 19 shows the stress contour and the deformation of the LIDS interface ring due to the most critical drogue parachute load case. The drogue parachute loads drive the sizing of all features in the local drogue application area as shown in Figure 19 (area of maximum deformation). TLI loads extracted from the TLI model's RBE2 elements were used to size the ring's top surface. Internal pressure sized the pressure seal lip and local gussets. Further work will be 
completed in this area to evaluate deflection requirements in order to ensure proper sealing for an internal pressure loads test. The peak ultimate von Mises stress was 63,920 psi. This resulted in a margin of safety of +0.03 for yielding and +0.08 for the ultimate load. The peak ultimate von Mises stress was 63,920 psi and had a margin of safety of +0.03 for yielding and +0.08 for the ultimate load.

\section{Forward Bay Gussets}

A detailed FEM of the upper pressure shell section above the splice line was developed for local sizing and failure analysis checks of the forward bay gussets including the gusset webs and the gusset caps. The model shown in Fig. 20 was merged at the splice line with the CCM global FEM and had 80,763 elements and 77,448 nodes. The various color regions represent regions of the same lay-up (PCOMP) in the model. The property regions in the detailed upper pressure shell section FEM differed slightly compared to the property regions in the global FEM because the global FEM was updated just prior to CDR. The updates in the global FEM included tapering of the solid laminate regions to the sandwich regions. The updates are not expected to significantly affect the local sizing or margin of safety of the gussets, but nevertheless will be included in the detailed upper pressure shell section model in the future. The gusset caps in the detailed upper pressure shell section FEM were modeled with a layer of elements that was attached to the elements of the LIDS interface ring with stiff CBUSH elements representing the fasteners. Similarly, the gusset cap elements were attached to the main parachute fitting elements with CBUSH elements to model the bolted connection. Lastly, the main parachute fittings were attached to the pressure shell OML with CBUSH elements to model to the bolted connection. The forces of the CBUSH elements were utilized to size for bearing loads.

A linear static analysis was performed in MSC Nastran ${ }^{\circledR}$ using the abort, TLI, and landing load cases. Figure 21 shows the application of landing loads (parachute) on the main parachute fittings. An upward vertical ultimate $\left(0^{\circ}\right)$ load of 64,413 lbs was applied to a node on the main parachute fitting. The load was then applied at a $20^{\circ}$ angle and clocked around every $45^{\circ}$ in a circular fashion on three main parachute fittings. HyperSizer $^{\circledR}$ was used to size the forward bay gussets and check the MS. Several iteration loops of running MSC Nastran ${ }^{\circledR}$ and HyperSizer ${ }^{\circledR}$ were performed to achieve convergence. Figure 22 shows the controlling load cases for the gussets from the HyperSizer $^{\circledR}$ analysis. The drogue parachute loads controlled the sizing of the gusset cap on the drogue gusset and the TLI loads controlled the sizing of the other five gusset caps. The main parachute loads controlled the sizing of the lower ends of the gusset caps on the main parachute fittings. Figure 23 shows the deformation of one of the gusset caps due to a parachute load. The parachute loading causes lateral bending in the gusset cap. The sizing of the gusset webs was driven by internal pressure, TLI, and the drogue parachute loads. Figure 24 shows the controlling failure analyses for the gussets from the HyperSizer $^{\circledR}$ analysis. The controlling failure analysis is defined as the type of analysis (composite strength, core strength, joint failure, panel buckling, etc.) in HyperSizer ${ }^{\circledR}$

causing the lowest MS for an element. The majority of the elements in the gusset webs and gusset caps were controlled by the composite Hoffman failure criterion. Some 
elements on the Pi-preform joints were controlled by pull-off or shear loads. Figure 25 shows a strain contour plot and MS plot for the gusset webs. The controlling load case was a TLI load case and the controlling failure analysis was the composite Hoffman failure criterion for the gusset web facesheets. Figure 26 shows a strain contour plot and margin of safety plot for the drogue gusset cap. The controlling load case was a drogue parachute load case and the controlling failure analysis was the composite Hoffman failure criterion. The other gusset caps were controlled by other load cases and are not shown. The bolted sections of the gusset caps were sized for bearing loads from the maximum CBUSH element forces.

The Pi-preform joints were also analyzed for failure (pull-off and shear) in HyperSizer ${ }^{\circledR}$ using the design allowables from the Pi-preform joint tests. Figure 27 shows the Pipreform joint definitions for the forward bay gussets. The blue elements in the enlarged detail region of the joints represent the gusset web and the green and yellow elements represent the two sides of the pressure shell skin OML. HyperSizer ${ }^{\circledR}$ defines a joint as the connecting lines between FEM nodes that are in common between 2 or 3 intersecting planes. The $\mathrm{N}_{\mathrm{x}}$ force is aligned in this direction along the joint, and the $\mathrm{N}_{\mathrm{y}}$ force is perpendicular to this direction. The Pi-preform shear load is defined as $\mathrm{N}_{\mathrm{xy}}$ along the joint interface. The $\mathrm{N}_{\mathrm{y}}$ force (joint pull-off) and the $\mathrm{N}_{\mathrm{xy}}$ force (joint shear) are used in the Pipreform bonded joint analysis and are calculated by using the peak FEA element corner forces. Figure 28 shows the margin of safety for the Pi-preform joints for the forward bay gussets. The elements in red (highlighted by the red circles) are local hot spots with negative margins at the Pi-preform termination regions. These regions require a detailed three-dimensional (3-D) FEM to accurately address the load distribution near the Pipreform termination in the upper and lower gusset caps. A detailed 3-D FEA is currently being performed to check for failures of the Pi-preform joints.

\section{Summary}

Structural design, sizing, and analysis have been performed on a CCM. The CCM project is managed by the NESC with participants from eight NASA Centers, the Air Force Research Laboratory, and multiple aerospace contractors. The CCM Project had a PDR in June 2007 and a CDR in December 2007. The CCM is a composite pressure module that is divided into upper and lower shell sections that mate together with a bonded belly band slice joint. This paper presents the structural design, sizing, and analysis of the upper pressure shell section including local details of the CCM. The upper pressure shell is a combined sandwich and solid laminate construction with IM7/977-2 used for the facesheets and solid laminates, and an aluminum non-perforated core used for the sandwich core. The upper pressure shell consists of several components including the metallic LIDS interface ring, LIDS/tunnel attachment, main and drogue parachute fittings, forward bay gussets and gusset caps, and the window and main hatch cutouts.

A global FEM of the CCM was developed and a finite element analysis (FEA) was performed using MSC Nastran ${ }^{\circledR}$ for an enveloped set of the design loads. The HyperSizer $^{\circledR}$ structural sizing software tool was used in sizing and post processing of the 
results of the CCM. FEA and HyperSizer ${ }^{\circledR}$ results including strains, deformations, margin of safety, and controlling load cases were presented for the global CCM FEM. The HyperSizer ${ }^{\circledR}$ results showed that the controlling load case driving most of the sizing in the upper pressure shell section was the internal pressure load case. The regions around the cutouts were controlled by internal pressure and the main parachute load cases. The global FEA results showed that the majority of the elements of the CCM had a positive MS with the exception of a few hot spots around the cutouts. These hot spots are currently being investigated with a more detailed analysis. Local finite element models of the LIDS interface ring and the forward bay gussets with greater mesh fidelity were created for local sizing and analysis. The sizing of the LIDS interface ring was driven by the drogue parachute loads, TLI loads, and internal pressure. The drogue parachute loads controlled the sizing of the gusset cap on the drogue gusset and TLI loads controlled the sizing of the other five gusset caps. The main parachute loads controlled the sizing of the lower ends of the gusset caps on the main parachute fittings. The results showed that the gusset web/pressure shell and gusset web/gusset cap interfaces bonded using Pi-preform joints had local hot spots in the Pi-preform termination regions. These regions require a detailed 3-D analysis, which is currently being performed, to accurately address the load distribution near the Pi-preform termination in the upper and lower gusset caps.

\section{References}

Kirsch, M., Gates, T., Alexandrov, N., Arnold, S., Bednarcyk, B., Feldhaus, W., Miura, H., Fernandez, I., Paddock, D., Nettles, A., Clowdsley, M., Sleight, D., Pelham, L., Jackson, K., Grunsfeld, J., and MacConnell, J., “Composite Crew Module (CM) Pressure Vessel Assessment Phase I Technical Report,” NASA NESC Report, 2007.

Bednarcyk, B., Arnold, S., Collier, C., and Yarrington, P., "Preliminary Structural Sizing and Alternative Material Trade Study of CEV Crew Module,” NASA/TM-2007-214947, 2007.

HyperSizer Structural Sizing Software, Collier Research Corp., Hampton, VA, http://www.hypersizer.com, 2007.

MSC Nastran, MSC Software Corporation, Santa Ana, CA, http://www.mscsoftware.com, 2005.

Hoffman, O., “The Brittle Strength of Orthotropic Materials,” Journal of Composite Materials, Vol. 1, No. 2, pg. 200-206, 1967. 


\begin{tabular}{|c|c|c|c|c|}
\hline Mission Phase & Load Case & Description & Magnitude & Cabin $\Delta \mathrm{P}$ \\
\hline \multirow{2}{*}{ Liftoff } & \multirow{2}{*}{ Liftoff } & \multirow{2}{*}{ Inertial Load Factors } & Axial $=3.3 /-2.0 \mathrm{G}$ 's & $0 \mathrm{psi}$ \\
\hline & & & Lat. $=1.5 \mathrm{G}$ 's (RSS) & $0 \mathrm{psi}$ \\
\hline \multirow{5}{*}{$1^{\text {st }}$ Stage Ascent } & Max-Q & $\begin{array}{c}\text { Inertial Loads \& } \\
\text { Dynamic Pressure }\end{array}$ & $\begin{array}{c}\text { Axial = } 2.4 \mathrm{G}^{\prime} \mathrm{s} \\
\text { Lat }=0.16 \mathrm{G} \mathrm{s} \\
\mathrm{Q}=1038 \mathrm{psf}\left(6^{\circ}\right)\end{array}$ & $12.83 \mathrm{psi}$ \\
\hline & Max-G & Inertial Loads & $\begin{array}{l}\text { Axial }=4.3 \mathrm{G} \text { 's } \\
\text { Lat }=0.50 \mathrm{G} \text { 's }\end{array}$ & $15.55 \mathrm{psi}$ \\
\hline & Max-Q Divergent & $\begin{array}{l}\text { Inertial Loads \& } \\
\text { Dynamic Pressure }\end{array}$ & $\begin{array}{c}\text { Axial }=2.4 \mathrm{G} \text { 's } \\
\text { Lat }=0.16 \mathrm{G} \text { 's } \\
\mathrm{Q}=1004 \mathrm{psf}\left(10^{\circ}\right)\end{array}$ & $12.83 \mathrm{psi}$ \\
\hline & Max-Q Hardover & $\begin{array}{l}\text { Inertial Loads \& } \\
\text { Dynamic Pressure }\end{array}$ & \begin{tabular}{|c|} 
Axial $=2.4 \mathrm{G} ' \mathrm{~s}$ \\
Lat $=0.16 \mathrm{G} \mathrm{s}$ \\
Ang. Accel. $=10 \mathrm{deg} / \mathrm{s}^{2}$ \\
$\mathrm{Q}=1004 \mathrm{psf}\left(10^{\circ}\right)$
\end{tabular} & 12.83 psi \\
\hline & Burnout Hardover & Inertial Loads & $\begin{array}{c}\text { Axial }=3.9 \mathrm{G} \text { 's } \\
\text { Lat }=0.4 \mathrm{G} \text { 's } \\
\text { Ang. Accel. }=21 \mathrm{deg} / \mathrm{s}^{2} \\
\end{array}$ & $15.55 \mathrm{psi}$ \\
\hline $2^{\text {nd }}$ Stage Ascent & Max Accel & Inertial Load Factor & Axial $=5.0 \mathrm{G}$ 's & $15.55 \mathrm{psi}$ \\
\hline
\end{tabular}

Table 1. CCM Design Launch Load Cases.

\begin{tabular}{|c|c|c|c|c|}
\hline Mission Phase & Load Case & Description & Magnitude & Cabin $\Delta P$ \\
\hline \multirow{3}{*}{ Pad Abort } & Abort Thrust & Thrust Force & $548,485 \mathrm{lbs}$ & 0 psi \\
\hline & Blast Overpressure & $\begin{array}{c}\text { Quasi-static pressure } \\
\left(\begin{array}{c}0^{\circ} \text { symm blast } \& 45^{\circ} \\
\text { oblique blast })\end{array}\right.\end{array}$ & 15psi & 0 psi \\
\hline & $\begin{array}{c}\text { Combined Thrust \& } \\
\text { Overpressure }\end{array}$ & $\begin{array}{l}\text { Thrust Force and } \\
\text { Applied Pressure }\end{array}$ & 548,485 lbs, 15psi & 0 psi \\
\hline \multirow{4}{*}{ Abort During Boost } & $\begin{array}{c}\text { Ascent Abort } \\
\text { Max-Q Slow Divergent }\end{array}$ & $\begin{array}{c}\text { Inertial Loads \& } \\
\text { Dynamic Pressure }\end{array}$ & $\begin{array}{c}\text { Axial }=2.4 \mathrm{G}^{\prime} \mathrm{s} \\
\text { Lat }=0.16 \mathrm{G}^{\prime} \mathrm{s} \\
\mathrm{Q}=1004 \mathrm{psf}\left(10^{\circ}\right) \\
\end{array}$ & $12.83 \mathrm{psi}$ \\
\hline & $\begin{array}{c}\text { Max-Q } \\
\text { Hard Over }\end{array}$ & $\begin{array}{l}\text { Inertial Loads \& } \\
\text { Dynamic Pressure }\end{array}$ & \begin{tabular}{|c|} 
Axial $=2.4 \mathrm{G} ' \mathrm{~s}$ \\
Lat $=0.16 \mathrm{G}$ 's \\
Ang. Accel. $=10 \mathrm{deg} / \mathrm{s}^{2}$ \\
$\mathrm{Q}=1004 \mathrm{psf}\left(10^{\circ}\right)$ \\
\end{tabular} & $12.83 \mathrm{psi}$ \\
\hline & $\begin{array}{l}\text { Burnout } \\
\text { Hard Over }\end{array}$ & Inertial Loads & $\begin{array}{c}\text { Axial }=3.9 \mathrm{G} \text { 's } \\
\text { Lat }=0.40 \mathrm{G} \text { 's } \\
\text { Ang. Accel. }=21 \mathrm{deg} / \mathrm{s}^{2}\end{array}$ & $15.55 \mathrm{psi}$ \\
\hline & High Altitude Abort & Thrust Force & $575,909 \mathrm{lbs}$ & $15.55 \mathrm{psi}$ \\
\hline
\end{tabular}

Table 2. CCM Design Abort Load Cases. 


\begin{tabular}{|c|c|c|c|c|}
\hline Mission Phase & Load Case & Description & Magnitude & Cabin $\mathbf{\Delta P}$ \\
\hline \multirow{7}{*}{ On-orbit Ops } & Cabin Pressure & $\begin{array}{c}\text { Applied Internal } \\
\text { Pressure }\end{array}$ & $\begin{array}{c}15.55 \mathrm{psi} \\
\text { (ISS) }\end{array}$ \\
\cline { 2 - 5 } & $\begin{array}{c}\text { TLI Burn } \\
\text { (EDS Thrust) }\end{array}$ & $\begin{array}{c}\text { Eyeballs out thrust } \\
\text { force w/cabin } \\
\text { pressure }\end{array}$ & $\begin{array}{c}293,750 \mathrm{lbs} \\
(\sim 1.4 \mathrm{~g} \text { 's burnout) }\end{array}$ & $9.5 \mathrm{psi}$ \\
\cline { 2 - 5 } & $\begin{array}{c}\text { Eyeballs out } \\
\text { (LSAM Thrust) }\end{array}$ & $\begin{array}{c}\text { acceleration w/cabin } \\
\text { pressure }\end{array}$ & $\sim 0.53 \mathrm{~g}$ 's (burnout) & $\begin{array}{c}9.5 \mathrm{psi} \max \\
0.0 \mathrm{psi} \min \end{array}$ \\
\cline { 2 - 5 } & $\begin{array}{c}\text { TEl Burn } \\
\text { (SM Thrust) }\end{array}$ & $\begin{array}{c}\text { Eyeballs in } \\
\text { acceleration w/cabin } \\
\text { pressure }\end{array}$ & $\sim 0.49$ g's (burnout) & $\begin{array}{c}9.5 \mathrm{psi} \mathrm{max} \\
0.0 \mathrm{psi} \text { min }\end{array}$ \\
\hline
\end{tabular}

Table 3. CCM Design On-Orbit Load Cases.

\begin{tabular}{|c|c|c|c|c|}
\hline Mission Phase & Load Case & Description & Magnitude & Cabin $\Delta P$ \\
\hline \multirow{5}{*}{ Atmospheric Entry } & ISS Nominal Direct & $\begin{array}{c}\text { Inertial Loads \& } \\
\text { Dynamic Pressure }\end{array}$ & $\begin{array}{c}\text { Axial }=4.16 \mathrm{G}^{\prime} \mathrm{s} \\
225 \mathrm{psf}\left(157^{\circ}\right)\end{array}$ & $9.5 \mathrm{psi}$ \\
\hline & ISS Ballistic & $\begin{array}{c}\text { Inertial Loads \& } \\
\text { Dynamic Pressure }\end{array}$ & $\begin{array}{c}\text { Axial = } 10.34 \mathrm{G}^{\prime} \mathrm{s} \\
646 \mathrm{psf}\left(158.3^{\circ}\right)\end{array}$ & $9.5 \mathrm{psi}$ \\
\hline & Lunar Skip & $\begin{array}{c}\text { Inertial Loads \& } \\
\text { Dynamic Pressure } \\
\end{array}$ & $\begin{array}{c}\text { Axial }=4.83 \mathrm{G}^{\prime} \mathrm{s} \\
297 \mathrm{psf}\left(160^{\circ}\right)\end{array}$ & $9.5 \mathrm{psi}$ \\
\hline & Lunar Ballistic & $\begin{array}{c}\text { Inertial Loads \& } \\
\text { Dynamic Pressure }\end{array}$ & $\begin{array}{c}\text { Axial = } 9.1 \mathrm{G}^{\prime} \mathrm{s} \\
560 \text { psf }\left(159.9^{\circ}\right)\end{array}$ & $9.5 \mathrm{psi}$ \\
\hline & Unpressurized Entry & $\begin{array}{l}\text { Cabin crush } \\
\text { pressure due to } \\
\text { venting lag }\end{array}$ & & -1 psi \\
\hline \multirow{6}{*}{$\begin{array}{l}\text { Recovery and } \\
\text { Landing }\end{array}$} & Chute Line Loads & Acceleration & $5 g^{\prime} s$ at $0^{\circ}$ & 0 psi \\
\hline & $\begin{array}{c}\text { Drogue Chute Line } \\
\text { Loads }\end{array}$ & Force & $\begin{array}{l}24,459 \text { lbs in } 40^{\circ} \text { cone } \\
\text { about X-axis applied at } \\
\text { the single attach } \mathrm{ftg} .\end{array}$ & $10.1 \mathrm{psi}$ \\
\hline & $\begin{array}{l}\text { Main Chute Line } \\
\text { Loads }\end{array}$ & Force & $\begin{array}{l}46,009 \text { lbs in } 20^{\circ} \text { cone } \\
\text { about X-axis applied at } \\
\text { each attach fitting }\end{array}$ & 3.35 psi \\
\hline & Horizontal Thrusters & Thrust of 2 retros & Lat. $=18,000 \mathrm{lbs}$ & $0 \mathrm{psi}$ \\
\hline & Land Landing & $\begin{array}{c}\text { Nominal Attenuation } \\
\text { at } 25 \mathrm{ft} / \mathrm{sec}\end{array}$ & $\begin{array}{c}8 g \text { 's reacted at CM } \\
\text { pressure vessel }\end{array}$ & 0 psi \\
\hline & Water Landing & One chute out & $\begin{array}{c}\text { Axial }=28.2 \mathrm{G} \text { 's } \\
\text { Lat }=10.1 \mathrm{G} \text { 's }\end{array}$ & 0 psi \\
\hline
\end{tabular}

Table 4. CCM Design Entry and Landing Load Cases. 


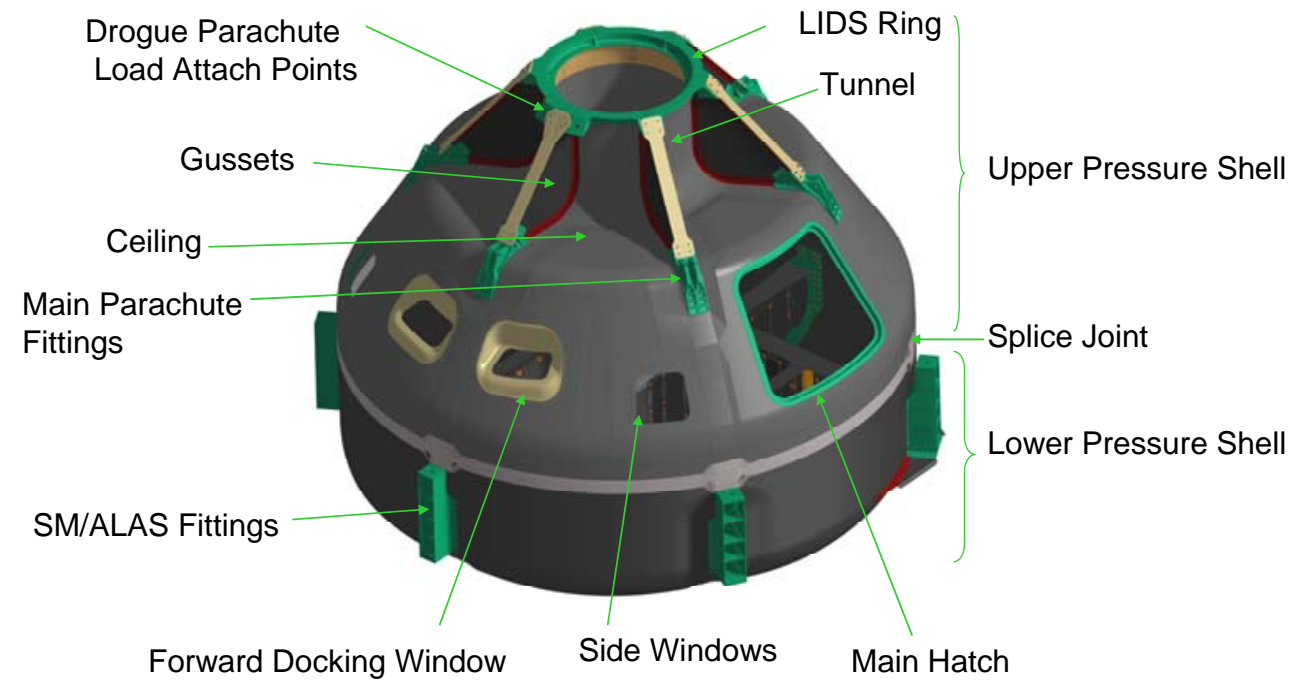

Figure 1. Composite Crew Module Geometry.

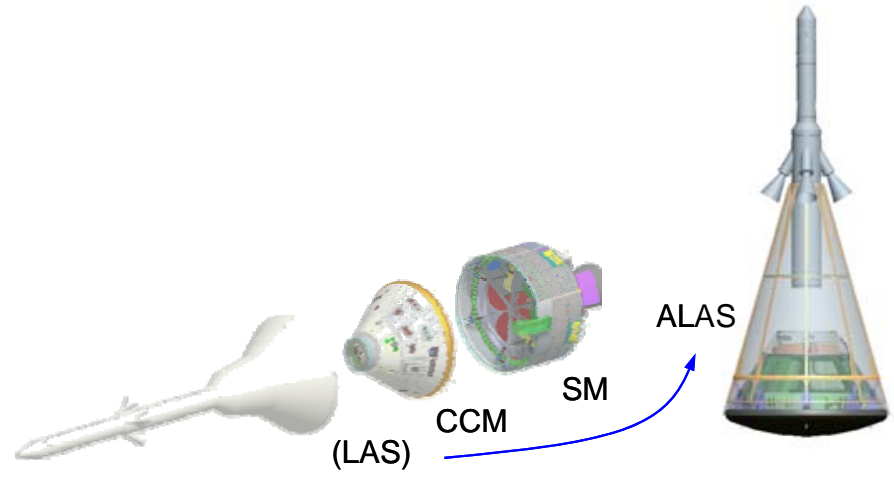

Figure 2. External Interfaces for Composite Crew Module.

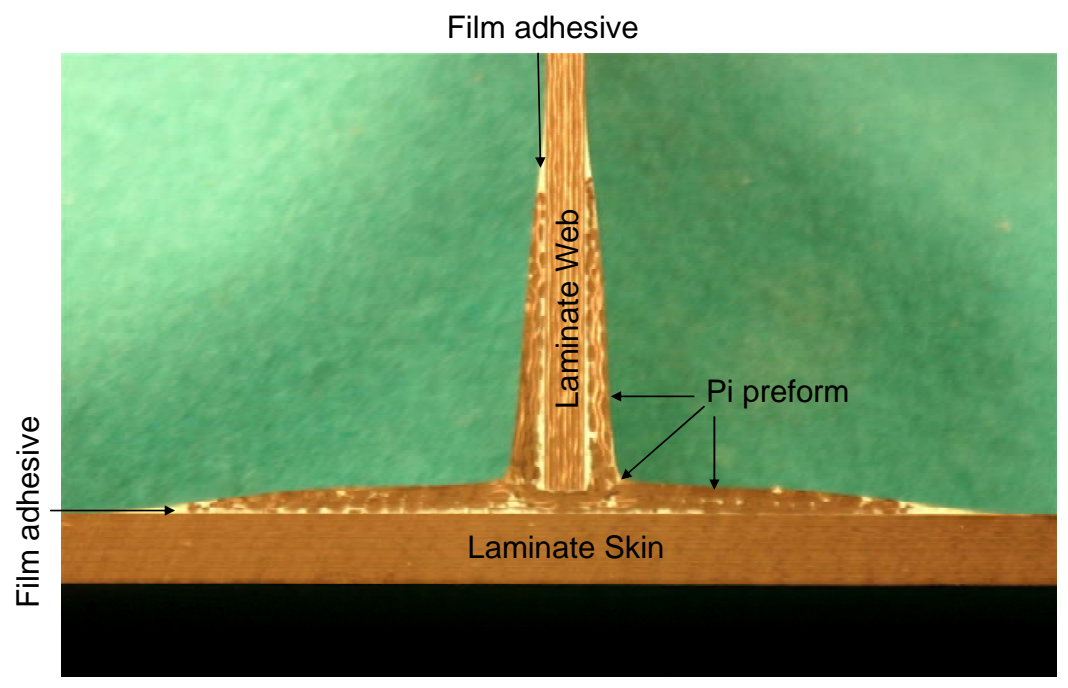

Figure 3. Details of a Pi-Preform Joint. 


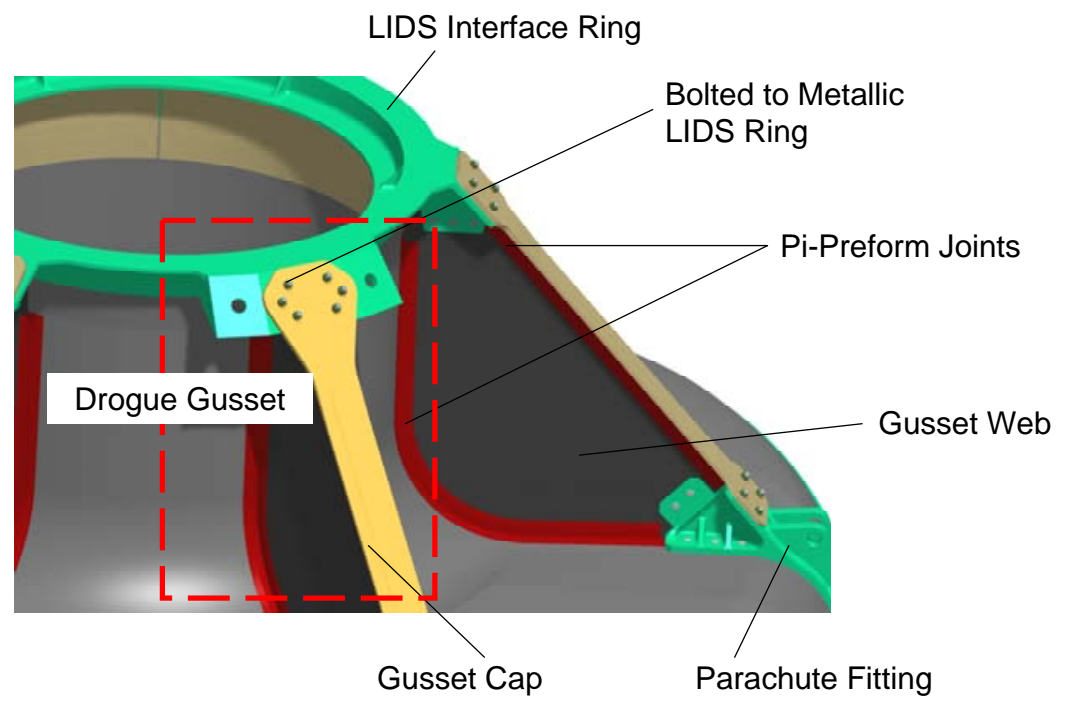

Figure 4. Design Details of the Upper Pressure Shell Section.

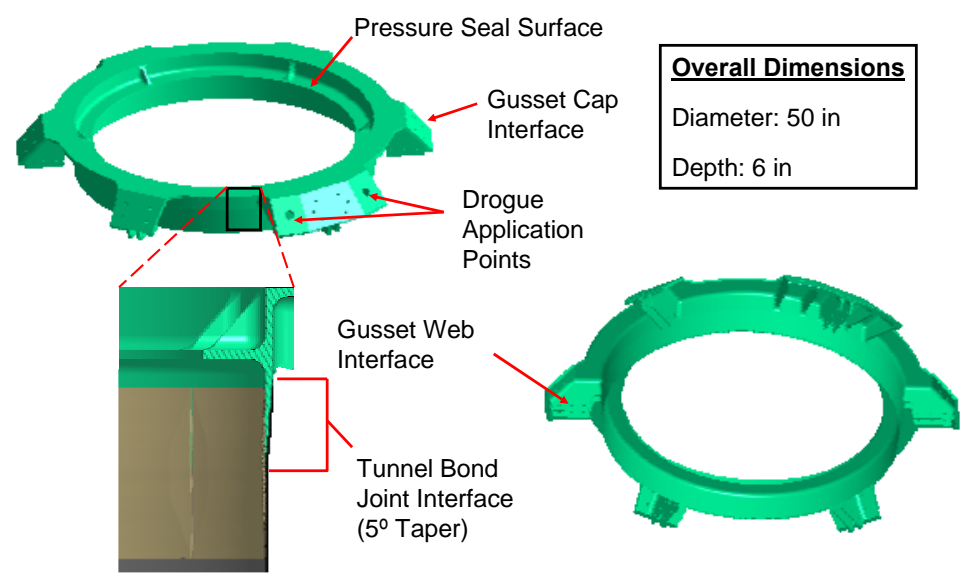

Figure 5. Design Details of the LIDS Interface Ring.

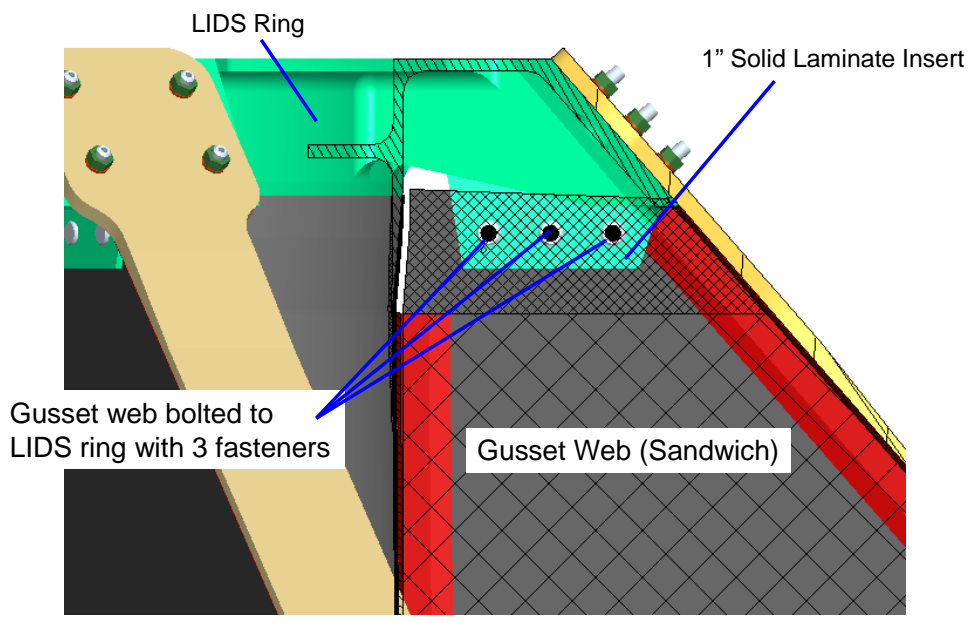

Figure 6. Design Details of the LIDS and Gusset Web. 


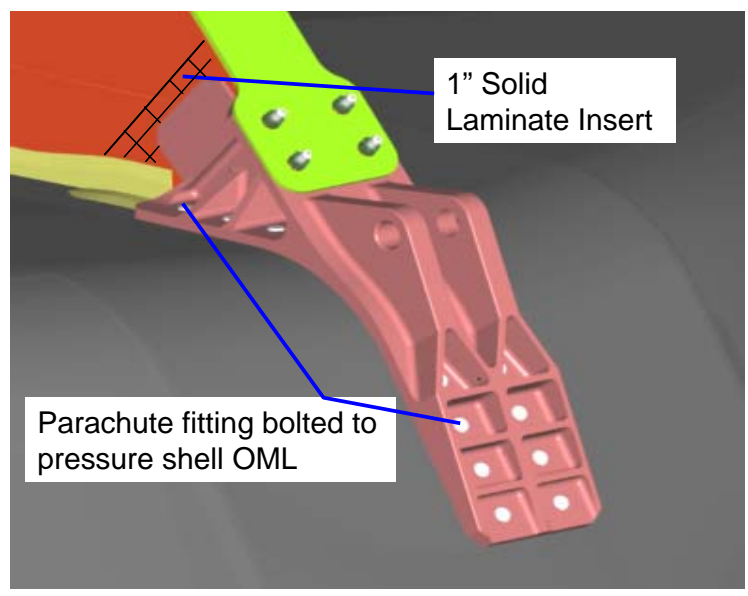

Figure 7. Design Details of the Gusset Web and Parachute Fitting.

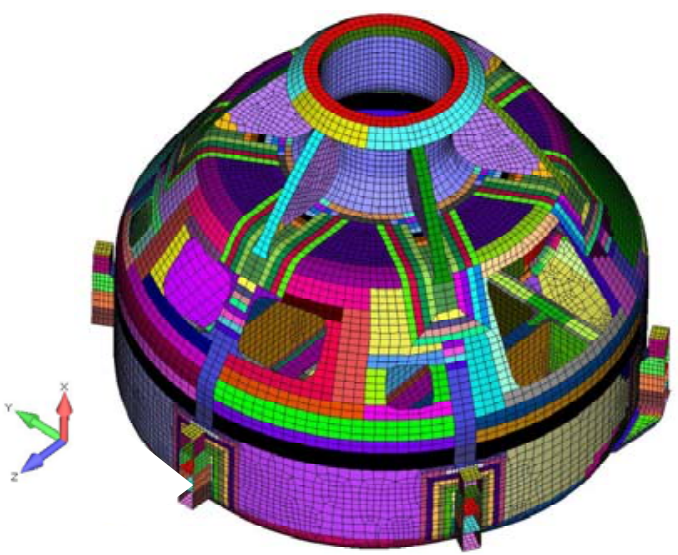

Figure 8. CCM Global Finite Element Model.

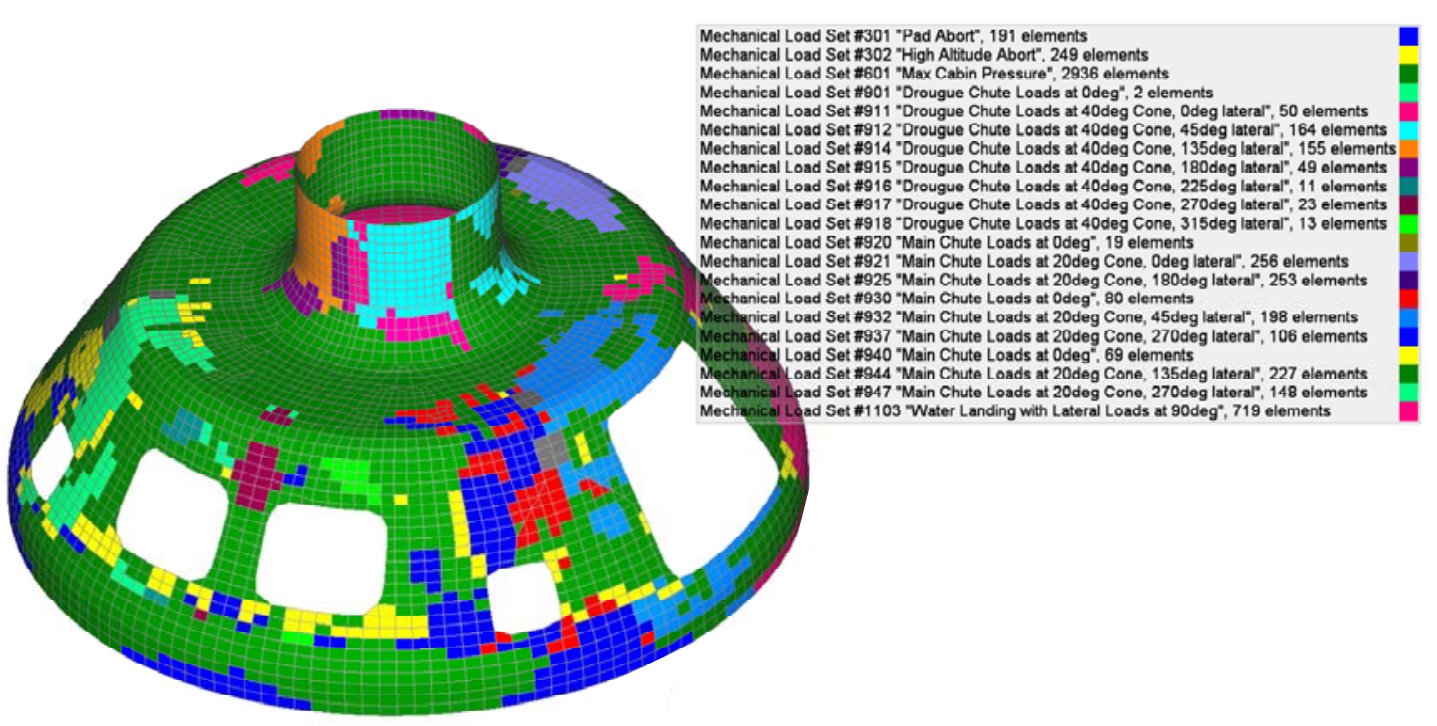

Figure 9. Controlling Load Cases for Upper Pressure Shell Section (Front). 


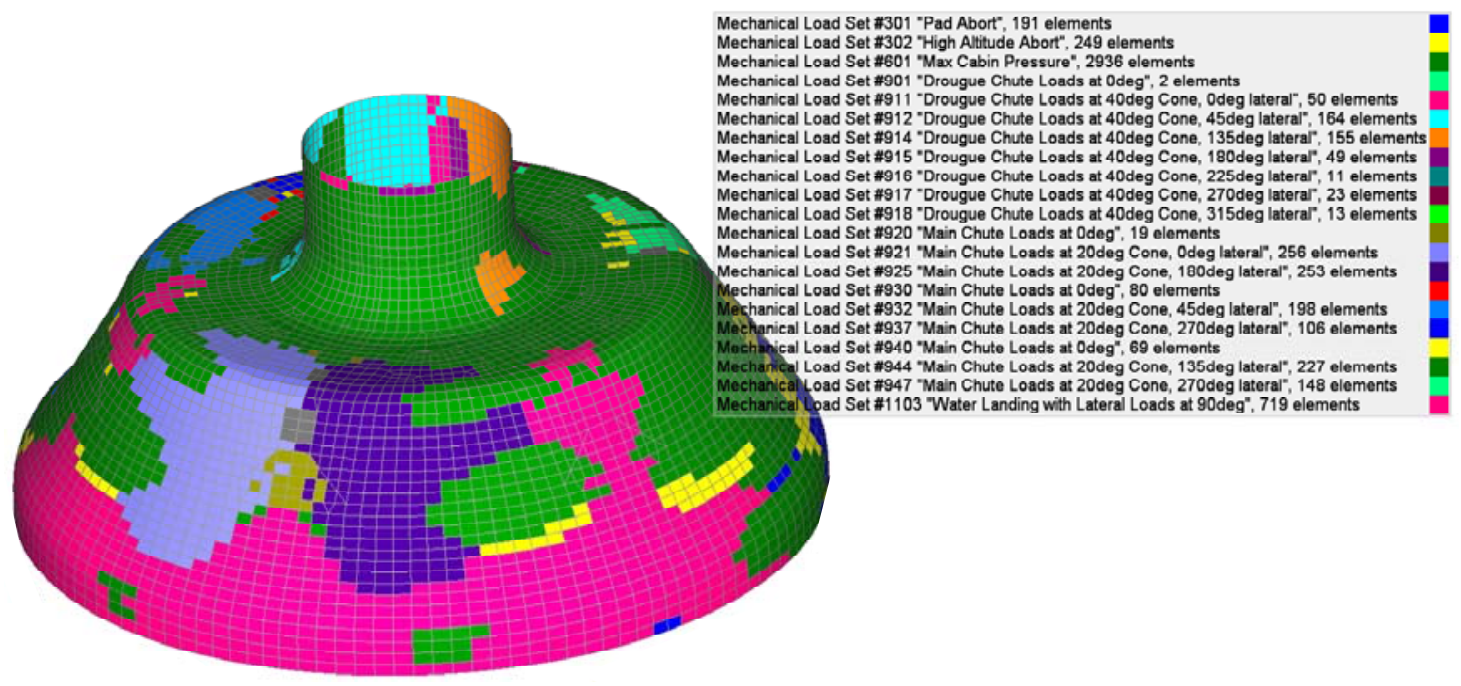

Figure 10. Controlling Load Cases for Upper Pressure Shell Section (Back).

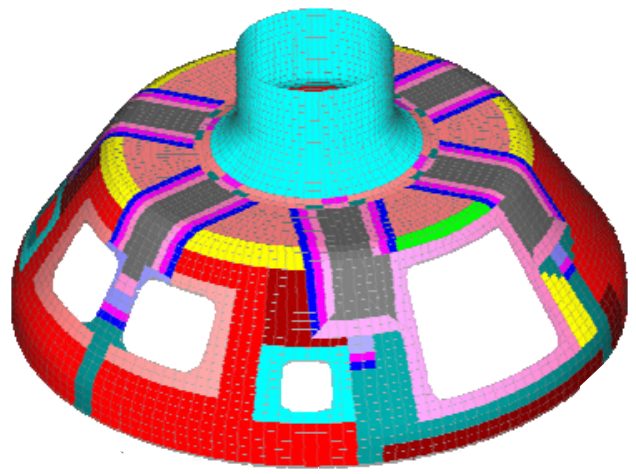

Front

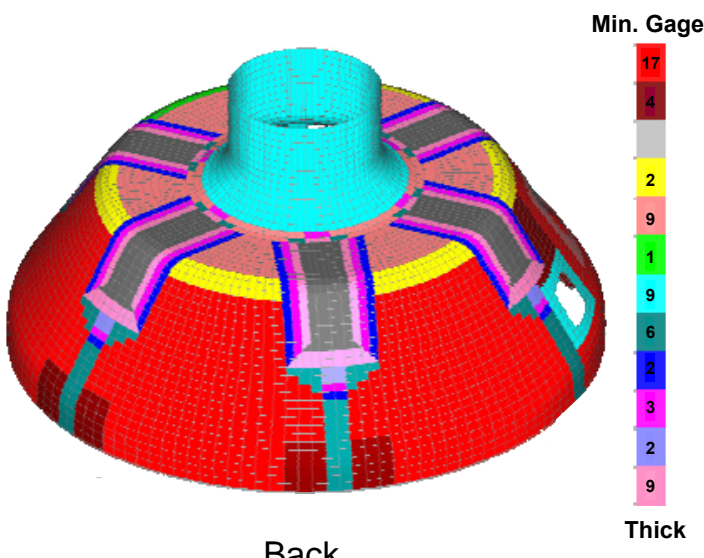

Back

Figure 11. Facesheet Thickness of Upper Pressure Shell Section.

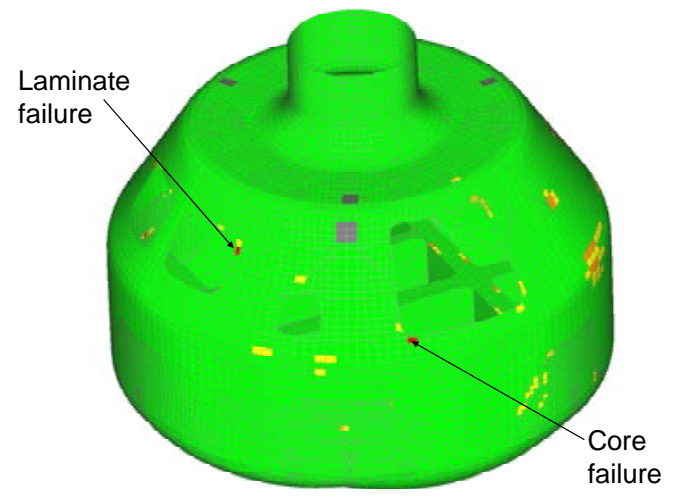

Front

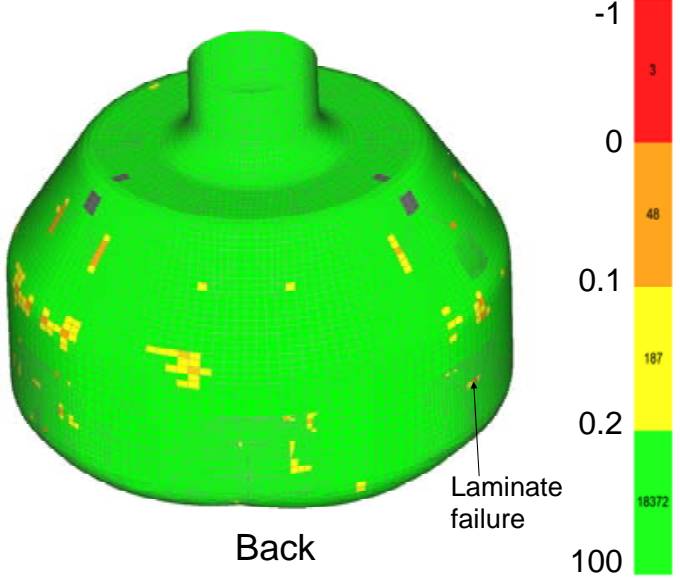

100

Figure 12. Margin of Safety Summary for CCM Global FEM. 


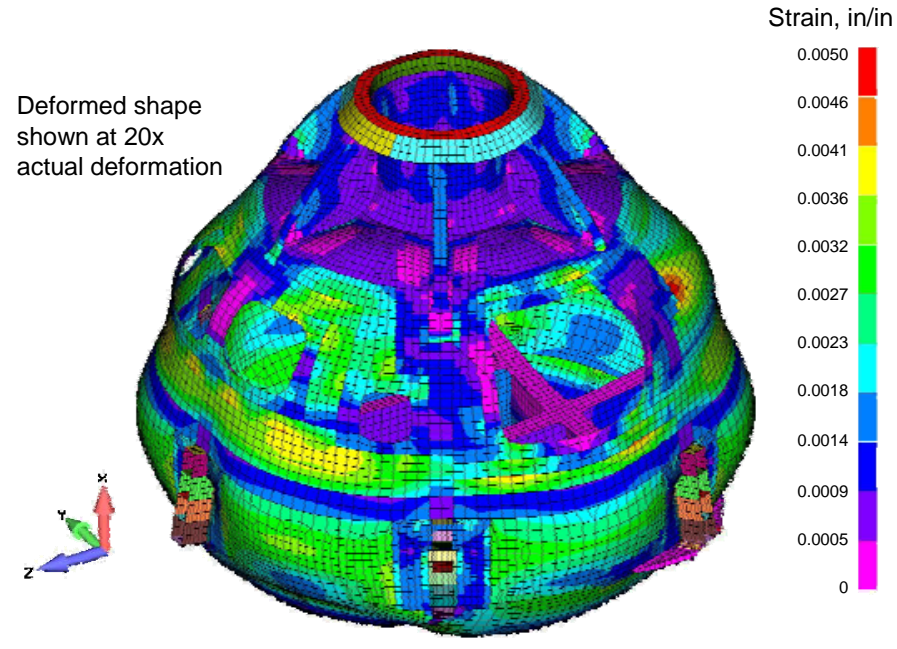

Figure 13. Strain Contour Plot of CCM Global FEM for Internal Pressure Load Case.
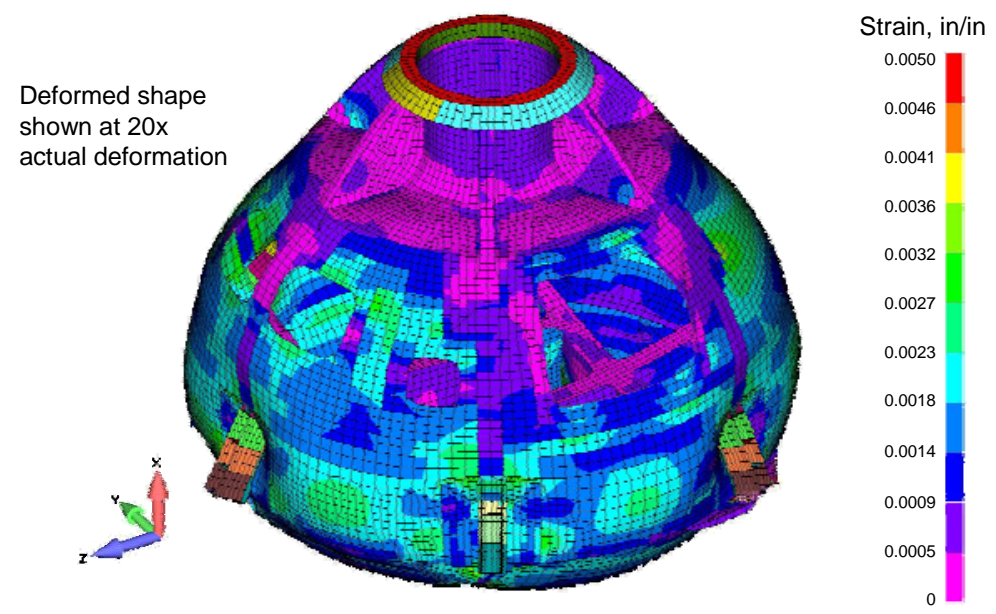

Figure 14. Strain Contour Plot of CCM Global FEM for High Altitude Abort Load Case.

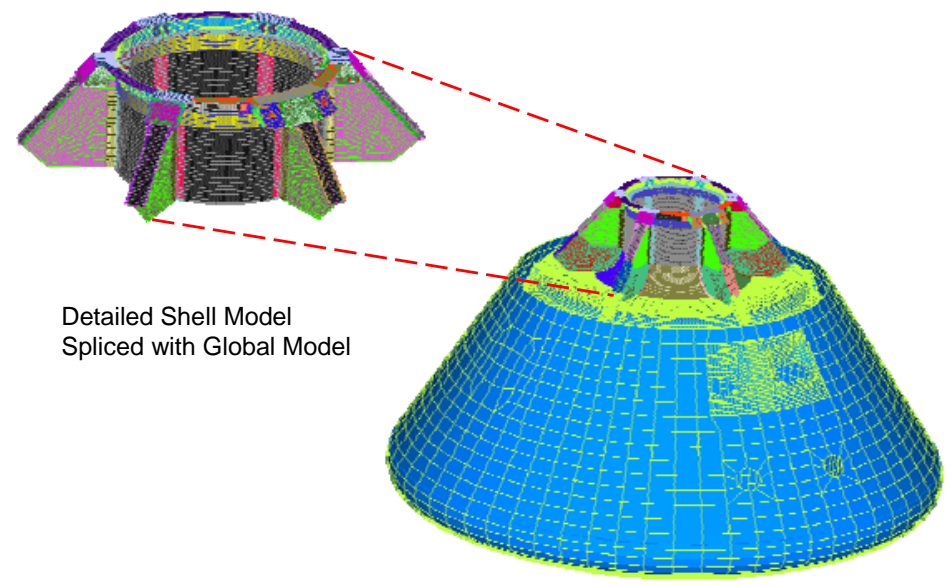

Figure 15. Detailed LIDS Interface Ring FEM. 


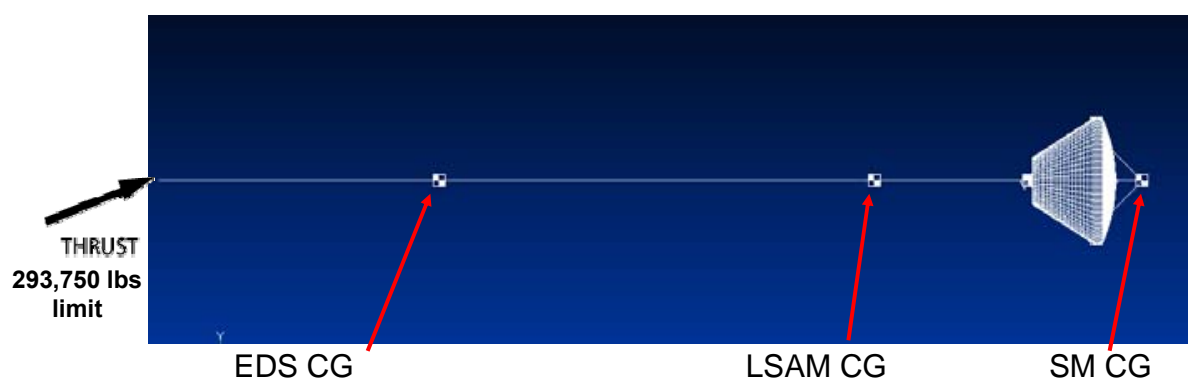

Figure 16. TLI Loading Condition.

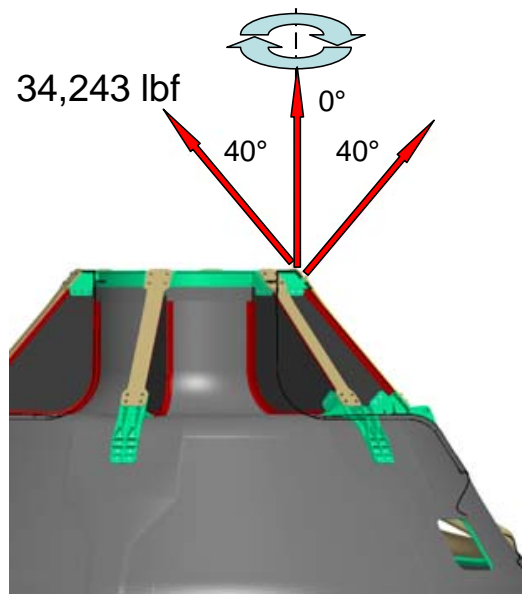

Figure 17. Drogue Parachute Loading Condition.

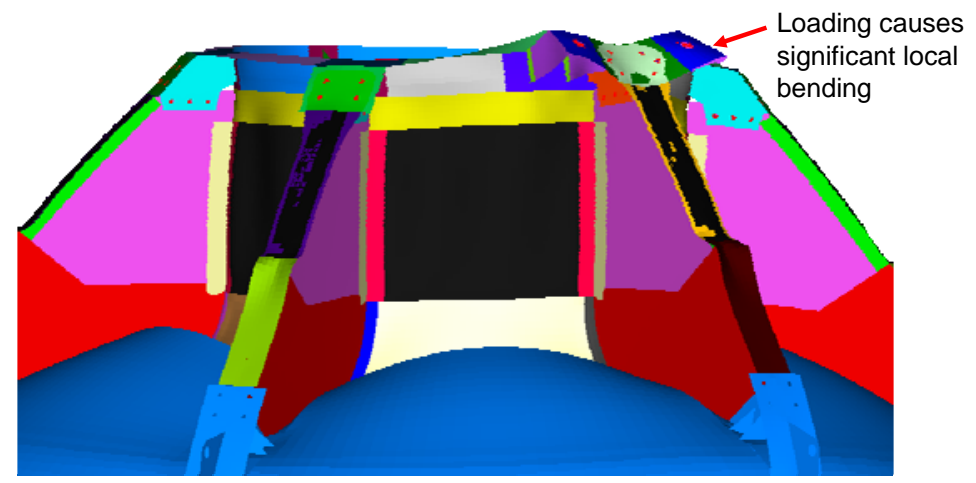

Figure 18. Deformation of LIDS Interface Ring Due to Drogue Parachute Load. 


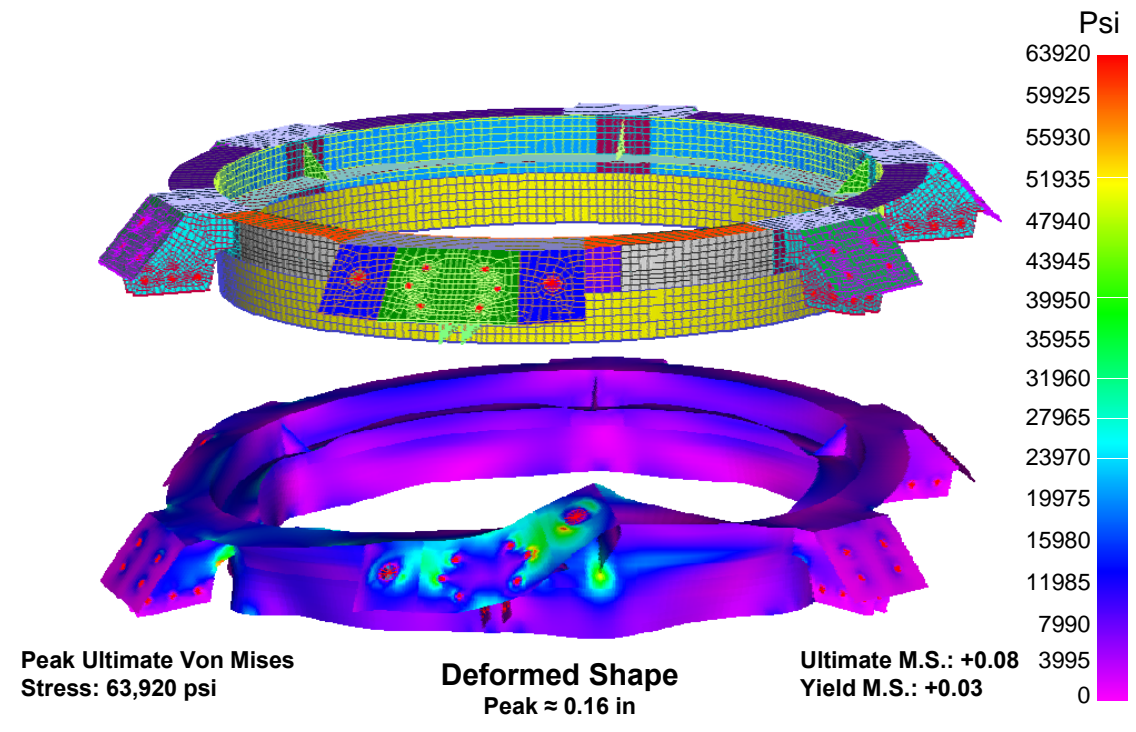

Figure 19. Stress Contour Plot of LIDS Interface Ring Due to Critical Drogue Parachute Load Case.

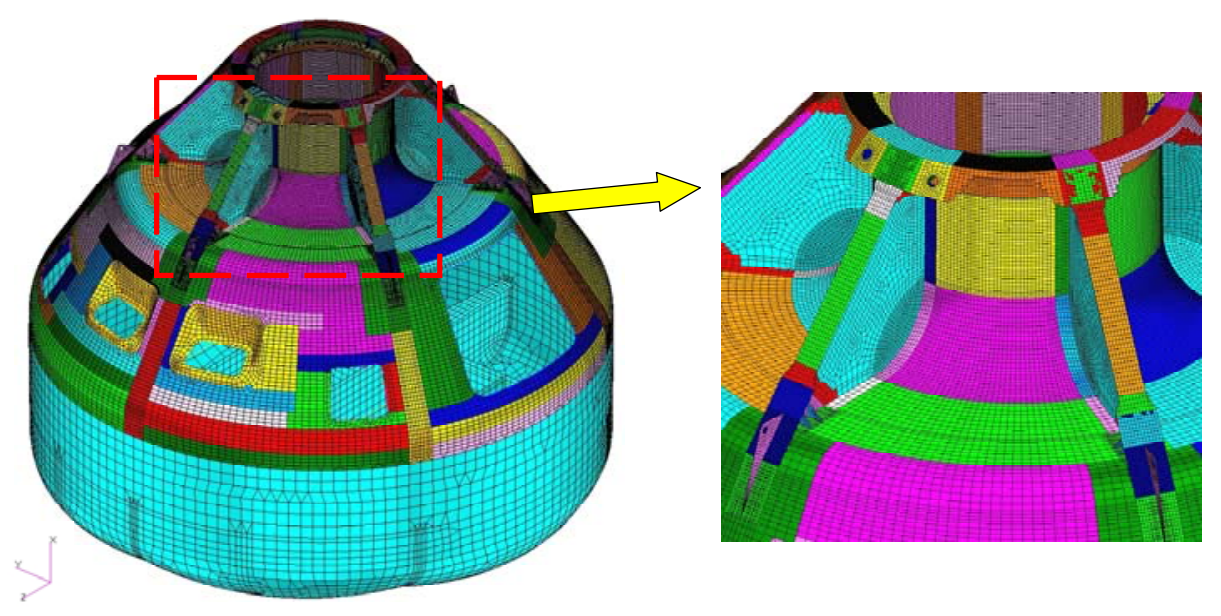

Figure 20. CCM Detailed Upper Pressure Shell Section FEM.

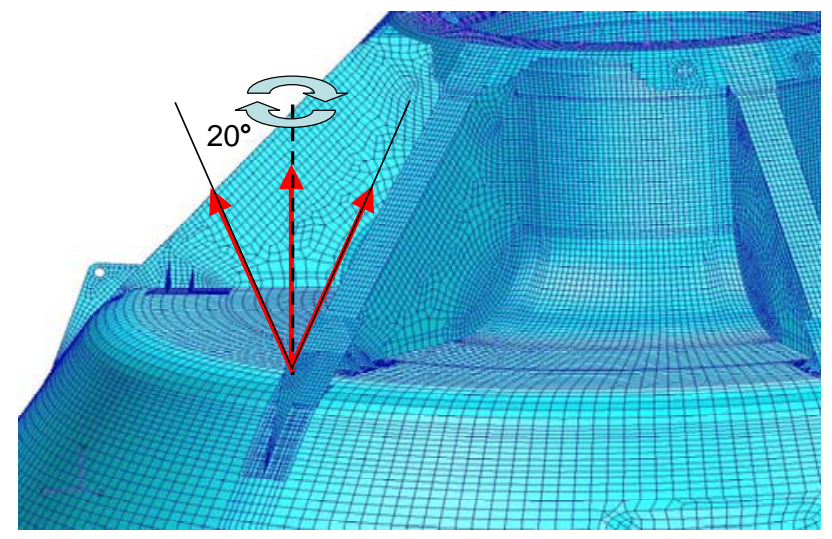

Figure 21. Main Parachute Loading. 

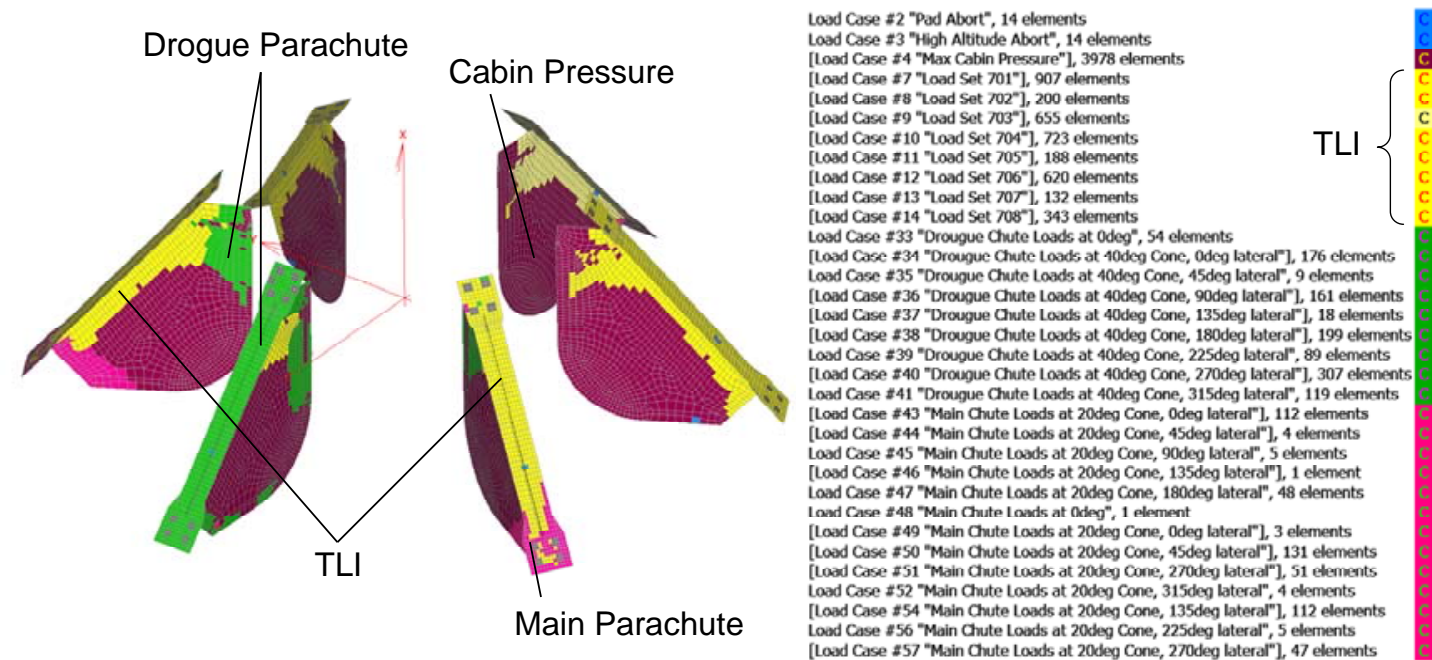

Figure 22. Controlling Load Cases for Forward Bay Gussets.

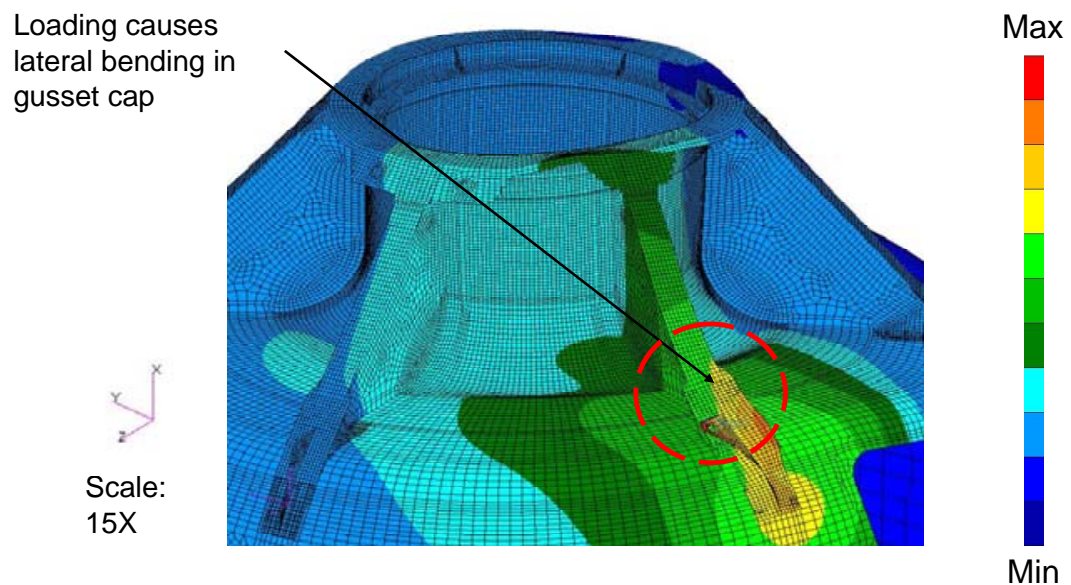

Figure 23. Gusset Deformation Due to Main Parachute Loading.

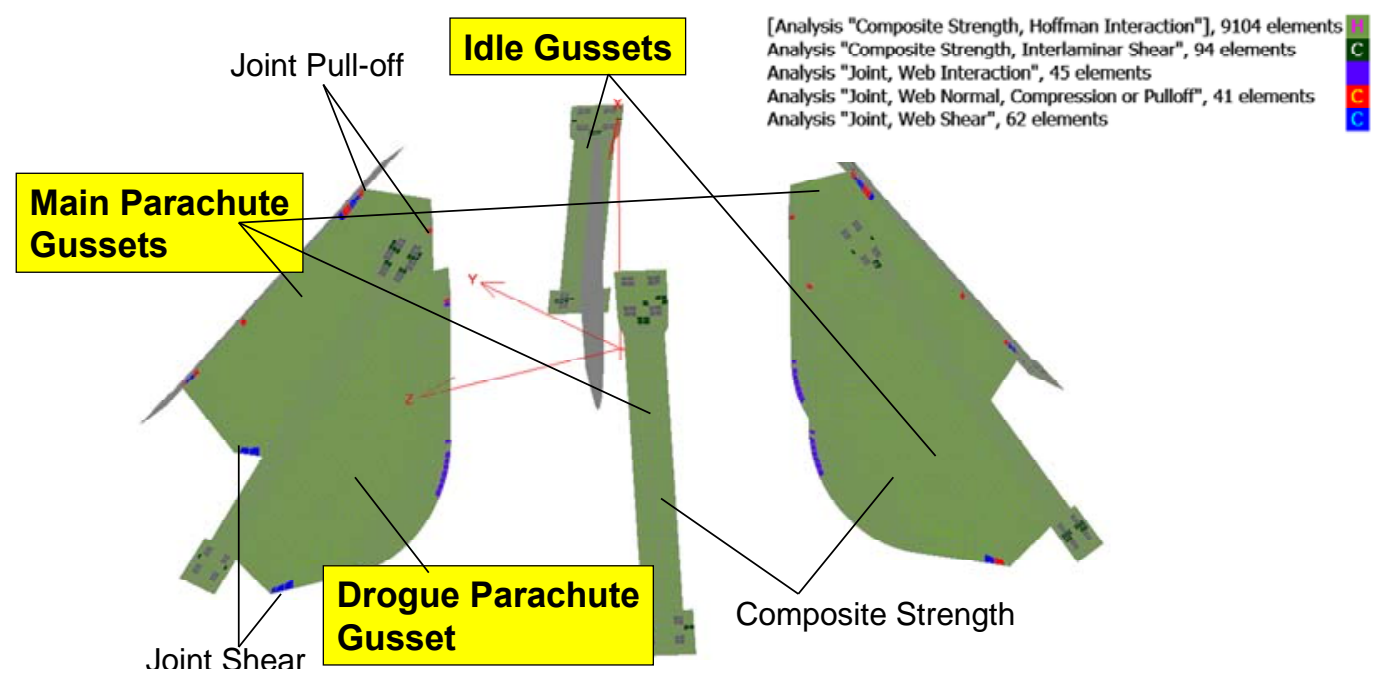

Figure 24. Controlling Failure Analysis for Forward Bay Gussets. 


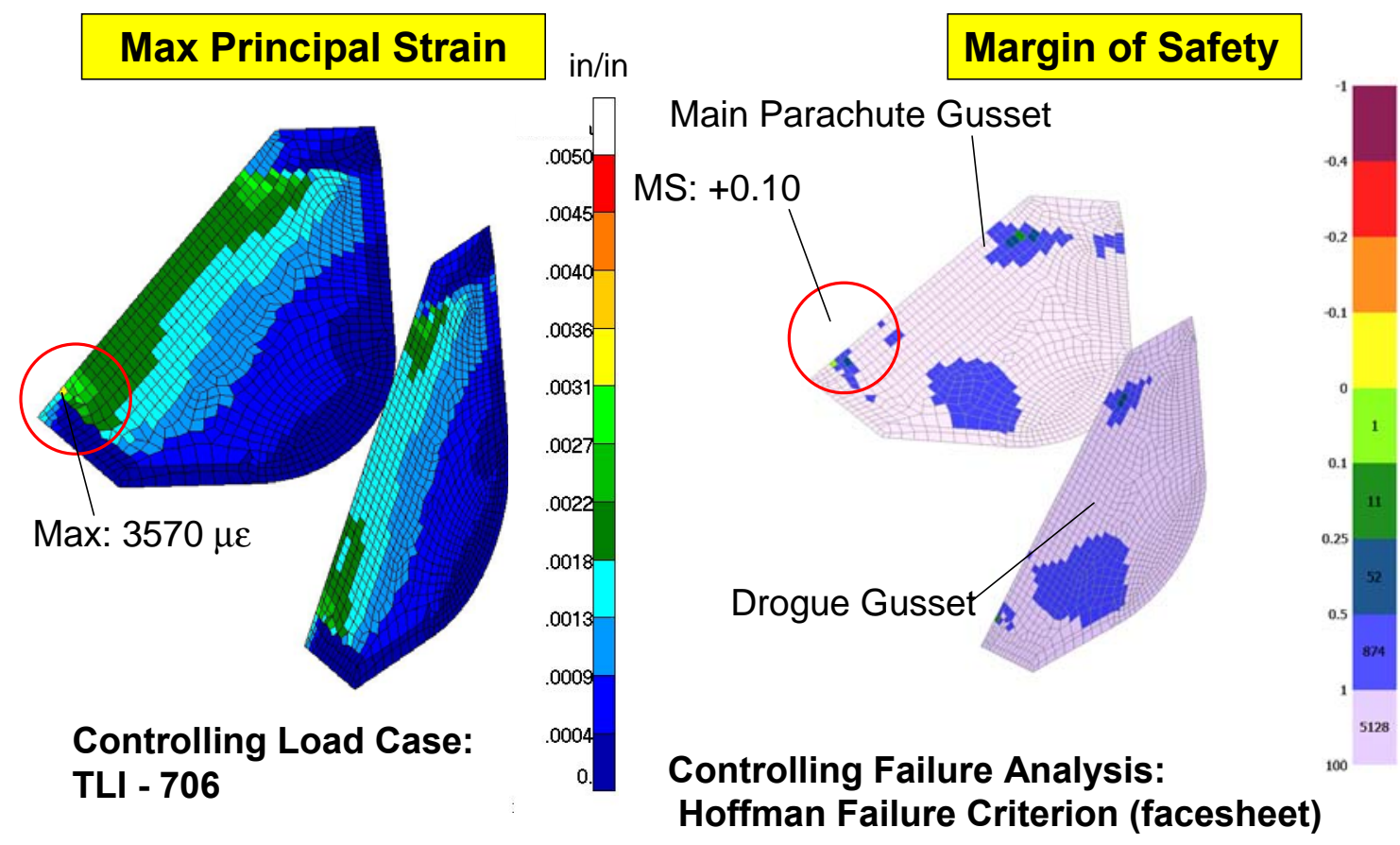

Figure 25. Strain Contour Plot and Margin of Safety Plot for Gusset Webs.

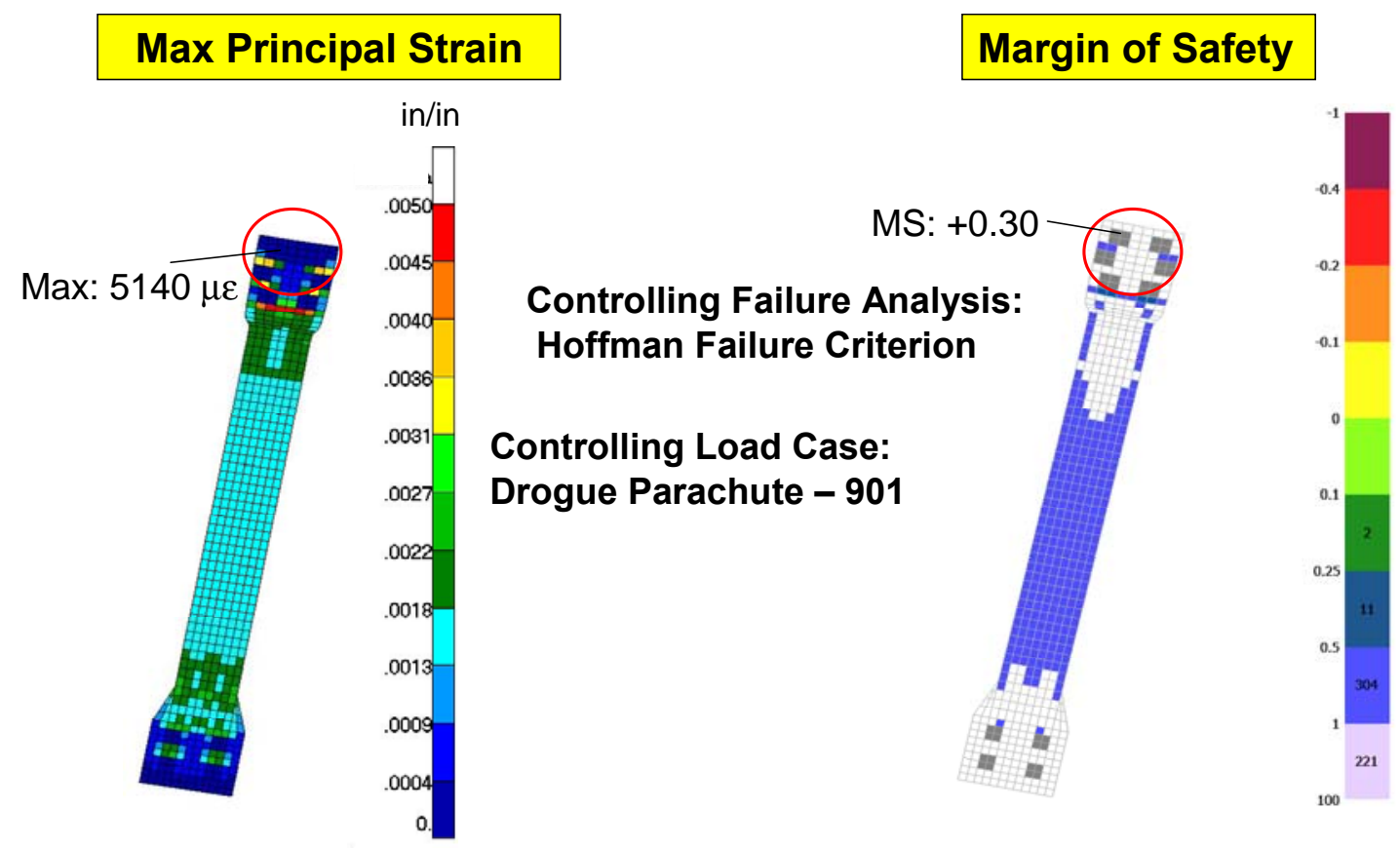

Figure 26. Strain Contour Plot and Margin of Safety Plot for Drogue Gusset Cap. 


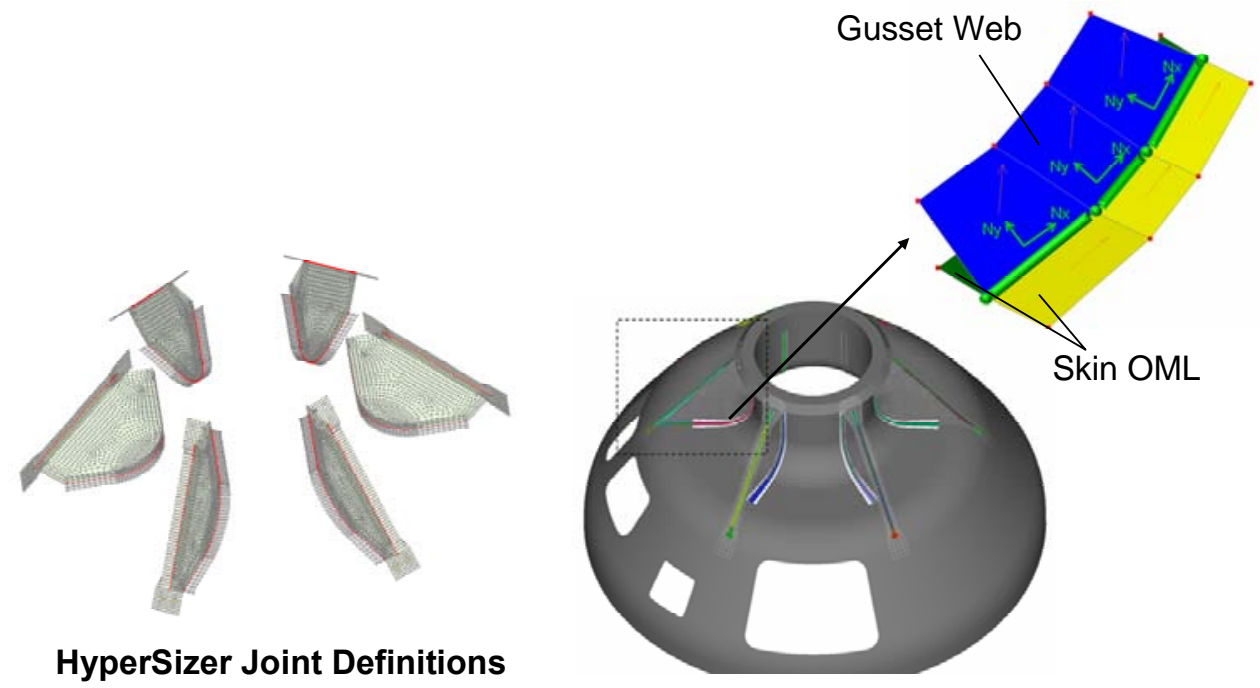

Figure 27. Pi-preform Joint Definitions for Forward Bay Gussets.

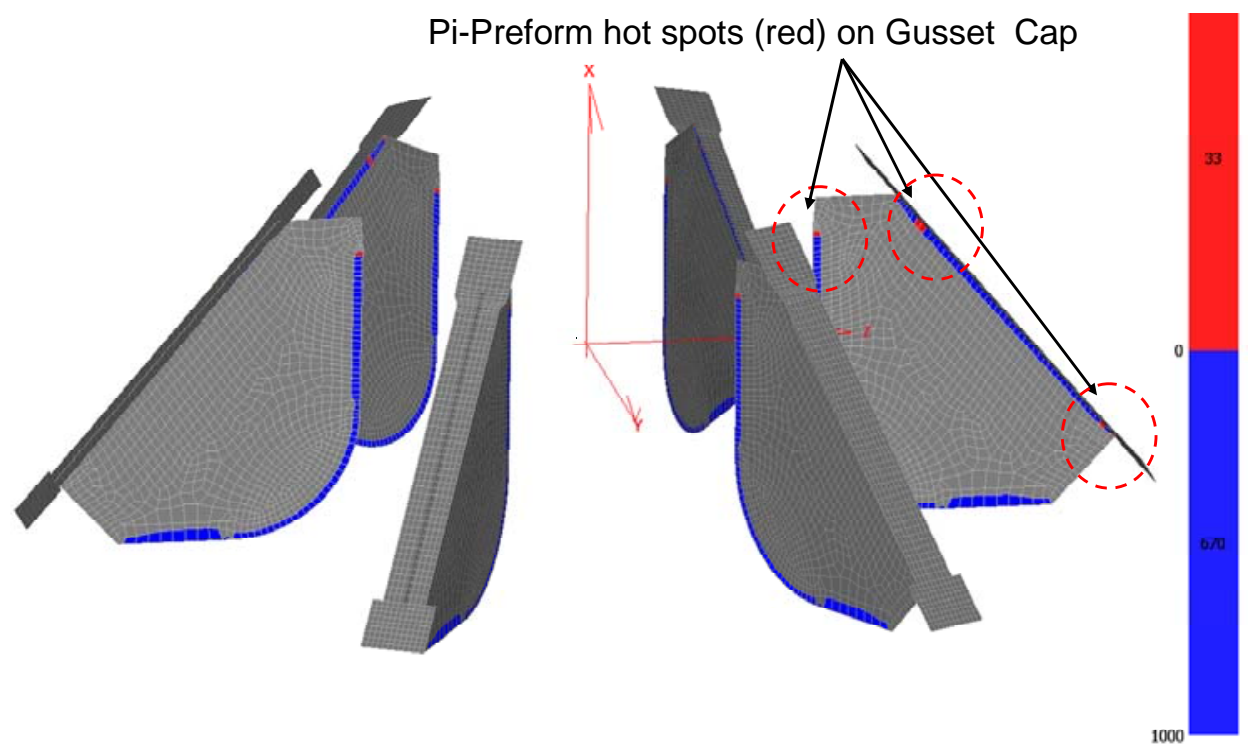

Figure 28. Margin of Safety for Pi-preform Joints for Forward Bay Gussets. 